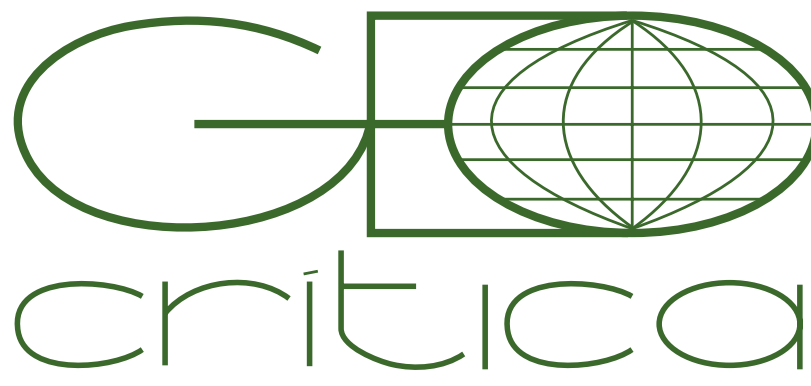

\section{Scripta Nova}

Revista Electrónica de Geografía y Ciencias Sociales Universitat de Barcelona

1 de enero de 2020

\title{
VIVIENDA Y MOVILIDAD. COMPORTAMIENTO RESIDENCIAL DE LA MIGRACIÓN CHINA EN ESPAÑA
}

\author{
Wanchu Zhong \\ wanchu0428@gmail.com

\section{Joaquín Beltrán Antolín} \\ joaquin.beltran@uab.cat \\ Universidad Autónoma de Barcelona
}

Recibido 17 de septiembre de 2018; Aceptado: 20 de mayo de 2019

Esta investigación forma parte del proyecto $I+D$ del Ministerio de Economía y Competitividad (FFI201570513-P MINECO/ FEDER, UE) "Asia Oriental: paradigmas emergentes, política(s) dinámicas socioculturales y sus consecuencias", así como del Grupo de Investigación Consolidado (GRC) Inter Asia y el nuevo sistema internacional: Sociedad, política y cultura (2017 SGR

1284) de la Generalitat de Catalunya.

\begin{abstract}
Vivienda y movilidad. Comportamiento residencial de la migración china en España. (Resumen)

En este artículo se analizan las características residenciales de la migración china en España. A partir del estado de la cuestión sobre su comportamiento residencial caracterizado por una elevada tasa de movilidad interna asociada fundamentalmente al trabajo y sus actividades económicas, se introducirán otros factores más específicos como los vínculos residenciales transnacionales. Las fases de la trayectoria residencial que incluyen el alojamiento en viviendas de emergencia y de transición hasta alcanzar la estabilidad residencial son objeto de análisis para el caso de la migración china. Finalmente, se exponen varias trayectorias residenciales de migrantes chinos en España donde se muestra la complejidad de la relación entre vivienda y movilidad con peculiaridades chinas.
\end{abstract}

Palabras clave: migración china, movilidad, vivienda, inversión extranjera en España

\section{Housing and mobility. Residential behavor of chinese migration in Spain (Abstract)}

This article analyses the housing characteristics of Chinese migration in Spain. Its residential behaviour is characterised by a high rate of internal mobility mainly associated with work and economic activities. Other more specific variables will be introduced, such as transnational housing links. The phases of the residential trajectory that include housing in emergency and transitional housing to achieve residential stability will be the subject of analysis for the case of Chinese migration. Finally, several residential trajectories of Chinese migrants in Spain are presented showing the complexity of the relationship between housing and mobility with Chinese peculiarities.

Key words: chinese migration, mobility, housing, foreign investment in Spain. 
La vivienda es una necesidad humana básica. La migración internacional conlleva la llegada de nueva población a los países del destino de sus flujos. Los nuevos residentes deben de ser alojados, lo cual dinamiza el mercado inmobiliario al aumentar la demanda de la compraventa y alquiler de viviendas, entre otros fenómenos relacionados. Al mismo tiempo, es habitual continuar manteniendo vínculos con la vivienda donde se residía antes de la movilidad y, con el paso del tiempo, incluso con nuevas viviendas adquiridas allí. En este sentido, la vivienda es uno de los aspectos a tener en cuenta en el transnacionalismo, pues proporciona un vínculo que traspasa las fronteras y en torno a ella se movilizan diferentes estrategias y prácticas, tanto para su acceso como para su uso. Cada país cuenta con sus propias características residenciales dominantes debido a factores históricos, estructurales y socioculturales, y son necesarias tenerlas en cuenta para comprender ciertos aspectos del comportamiento residencial de la población extranjera de diferentes orígenes nacionales.

La movilidad, en relación con la vivienda y la migración, incluye dos tipos diferenciados estrechamente relacionados con las trayectorias migratorias y el ciclo de vida. Por un lado, desde perspectivas y aproximaciones demográficas y geográficas, se ha analizado la movilidad interna de los migrantes internacionales residentes en un país de acuerdo a su alcance: dentro de una misma ciudad, cambiando la residencia -y por lo tanto de vivienda- de un barrio a otro; o entre municipios, sea a nivel intra-provincial -con las zonas metropolitanas como un caso específico- o inter-provincial; y junto a ello también se han abordado diversos fenómenos como la concentración/dispersión de migrantes de diferentes orígenes en determinadas zonas, o la, en parte asociada, situación de segregación/exclusión de otras.

Por otra parte, y con una perspectiva más sociológica y antropológica se han abordado otros aspectos, como los distintos tipos de vivienda a los que se accede a lo largo de la trayectoria vital ${ }^{1}$ y migratoria que coinciden en gran parte, con las fases de la misma, y así se pasa de la posibilidad de estar alojados en viviendas de emergencia en el momento de la llegada a vivir en otras de transición hasta alcanzar la estabilidad residencial ${ }^{2}$. La movilidad social y económica ascendente que puede producirse con el paso del tiempo gracias a la mejora de la situación socioeconómica de los migrantes y sus familias, suele ir acompañada de una movilidad residencial que logra la estabilidad con el alquiler o la compra de vivienda para uso unifamiliar y que cuenta, en general, con mejores condiciones de habitabilidad 3 .

En este artículo se analizará la migración china y su movilidad relacionada con la vivienda en España y en China, por lo tanto, se abordarán tanto sus prácticas transnacionales en relación con la vivienda en China y desde China a España, como su movilidad residencial interna en España en los dos niveles antes mencionados: el geográfico - de un barrio a otro, de una ciudad a otra- y el social -fases de emergencia a estabilidad pasando por transición-. En segundo lugar, también se presen-

1 Clark y Huang, 2003; Coulter y van Ham, 2013; Couter, Van Ham y Findlay, 2016

2 Pereda, Actis y Prada, 2005

3 Fullaondo, 2008; García y Frizzera, 2008 
tarán y analizarán las diferentes prácticas y estrategias movilizadas para el alquiler y compra de vivienda, incluida la procedencia del capital. Los cambios de vivienda coinciden con la evolución de la trayectoria migratoria a lo largo de la estancia en España, al mismo tiempo que se mantienen vínculos residenciales con China.

El artículo se estructura del siguiente modo. En primer lugar, se revisa el estado de la cuestión de la vivienda y migración china en España, a menudo encuadrada en estudios más generales, donde el origen chino o bien se (con)funde con la más amplia categoría de "asiáticos", o bien es un caso más de los analizados, aunque existen algunas excepciones de investigaciones donde los residentes chinos son los protagonistas. A continuación, se analizarán las características de las distintas fases residenciales y la procedencia de los ingresos para su alquiler o compra en España. Finalmente, se presentarán varios estudios de caso de trayectorias residenciales de migrantes que incluyen a China y España.

Los datos utilizados en este artículo proceden, por un lado, de la revisión bibliográfica de investigaciones, informes, estadísticas y noticias que abordan el fenómeno analizado; y por otro, de un trabajo de campo específico con observación participante y entrevistas en profundidad a informantes chinos sobre sus trayectorias, comportamientos, estrategias y prácticas en relación con su movilidad residencial transnacional e interna. El trabajo de campo se ha llevado a cabo durante dieciocho meses -desde noviembre de 2015 hasta mayo de 2017-principalmente en los municipios de Barcelona, Santa Coloma de Gramanet, L'Hospitalet de Llobregat, Castelldefels y Centelles, además de la ciudad de Madrid. En total, se han entrevistado a 60 personas. En el análisis cualitativo la voz de los informantes proporciona unos datos que complementan a las estadísticas que muestran indicadores y tendencias, y ayudan a describir una realidad que es explicada por sus protagonistas dando sentido y contenido a los análisis cuantitativos. El trabajo de campo se complementa con datos procedentes de otras investigaciones realizadas sobre la migración china en España desde el año 2000 hasta la actualidad, donde su relación con la vivienda no es central, pero hay referencias a la misma con mayor o menor profundidad.

\section{Breve perfil de la población china en España}

Los residentes chinos en España constituyen actualmente uno de los colectivos de extranjeros con mayor población: ocupan la quinta posición de todos los extranjeros y la segunda si sólo se tienen en cuenta a los extracomunitarios. A finales del año 2017 había 211.298 personas chinas con permiso de residencia a aque habría que sumar 8.604 estudiantes internacionales en esa misma fecha y una gran parte de los 8.130 nacionalizados desde 1995 hasta 2017, junto a sus descendientes, imposibles de contabilizar. A pesar de que la heterogeneidad de las personas de origen chino en España es evidente de acuerdo a diversos criterios y variables -lugar de origen concreto en China, rurales y urbanos, nivel educativo y de formación, clase social, inversores y trabajadores, etc.-, existe un segmento dominante -en el sentido de mayoritario por volumen de población- que convierte al nodo de la diáspora 
china en España en un caso único en el mundo porque procede de una zona rural muy pequeña -2.484 kilómetros cuadrados- localizada en el sur de la provincia de Zhejiang -distrito de Qingtian y los distritos vecinos que pertenecen a la prefectura de Wenzhou-. Aproximadamente la cuarta parte del total de los 500.000 habitantes de Qingtian (censo de 2010 de la República Popular China), residía en España.

El perfil de los residentes chinos en España es de familias jóvenes con hijas e hijos menores de edad. El 25\% de los residentes son menores de 15 años. Además, en el ámbito laboral cuentan con un gran porcentaje de trabajadores autónomos (53,6\% de los 101.535 dados de alta en la Seguridad Social en diciembre 2017) y muchos de ellos son efectivamente empresarios en el sector servicios -hostelería, comercio al por menor, peluquerías, etc.- y se encuentran repartidos por todo la geografía española. No obstante, existen algunas pequeñas concentraciones residenciales que han sido denominadas "Chinatown" por periodistas e investigadores ${ }^{4}$. Las expectativas de los migrantes de Qingtian es ser propietarios de negocios que habitualmente son pequeñas empresas familiares, circunstancia que los convierte en únicos frente al resto de los orígenes extranjeros que residen en España. Los chinos son "diferentes" y por eso en los análisis generales sobre la migración internacional en España su comportamiento y sus características a menudo no coinciden con el de los extranjeros extracomunitarios.

Además, al segmento "dominante" se suman otros de orígenes más recientes que también llaman la atención por su singularidad. Se trata de l) los estudiantes internacionales extracomunitarios -desde 2013 ocupan la primera posición de los mismos y su volumen no cesa de aumentar cada año-; y 2) los inversores, en un sentido amplio, que incluyen tanto a las empresas multinacionales chinas y el gran capital que las acompaña, como a quienes han obtenido la residencia gracias a la Ley 14/2013 de Apoyo a los Emprendedores y su Internacionalización, especialmente por la compra de bienes inmuebles por valor de 500.000 euros. Los procedentes de China ocupaban la primera posición de esta categoría residencial a finales de 2017 con un total de 997 inversores. En definitiva, los residentes de origen chino en España constituyen un grupo importante de migrantes internacionales y que continúa aumentando, aunque a un ritmo inferior a otras épocas, y cuya contribución a la economía nacional no pasa desapercibida.

\section{Estado de la cuestión sobre vivienda, movilidad y migración china en España}

Varios autores han abordado las definiciones conceptuales de movilidad residencial y migración, antes de aplicarlas a estudios concretos. Es un debate abierto y su alcance y uso depende de cada autor. En general y a modo de resumen, Palomares, Feria y Susino 5 , por ejemplo, argumentan que la "movilidad residencial" sólo debería de aplicarse a los cambios de domicilios intraurbanos -incluidos los producidos

4 Beltrán, 2000, 2005; Tébar, 2011; McDonough, 2013; Martínez-Rigol et al., 2017

5 Palomares, Feria y Susino, 2017 
dentro de las zonas metropolitanas, es decir entre los distintos municipios incluidos en cada zona metropolitana específica- frente a las "migraciones" que se aplicaría al cambio de residencia de un municipio a otro -o de una zona metropolitana a un domicilio fuera de ella-. El estudio de las migraciones internas de los extranjeros en España ha dado lugar a varias investigaciones como la de Recaño ${ }^{6}$, que destaca una "mayor intensidad migratoria de los extranjeros con relación a los españoles" y que "los extranjeros muestran una gran diversidad de patrones migratorios cuando se consideran diferentes nacionalidades".7 Este fenómeno es constatado también en un artículo más reciente donde afirma que "los inmigrantes muestran tasas más elevadas de movilidad que la población autóctona; sus desplazamientos son de mayor distancia y se caracterizan por una mayor flexibilidad en la localización dentro del territorio español", aunque la crisis económica "ha supuesto un descenso significativo de la movilidad de los inmigrantes" ${ }^{8}$. Recaño y Domingo 9 afirman que "muy escasos trabajos españoles han considerado la movilidad geográfica interna de este colectivo [extranjeros] como un tema relevante de análisis" aunque ellos consideran que se ha convertido en un factor estructural de los movimientos internos en España: "Los factores que explican la elevada movilidad espacial de la población extranjera en España son más complejos que los de la población nativa. Entre ellos cabe destacar el efecto de la duración de residencia, la búsqueda de vivienda y trabajo y las diversas fases de la dinámica familiar, al simultanear el proceso migratorio y las transformaciones propias del ciclo de vida familiar" ${ }^{\prime 10}$. Por su parte, Recaño y De Miguel ${ }^{11}$ realizan un estudio comparativo sobre los patrones de migración interna de la población nacida en el extranjero que incluye a Portugal, Italia y España, por su historia común de emigración para convertirse, desde mediados de la década de 1990 en destinos de inmigración. Entre sus conclusiones, además de resaltar la mayor intensidad de la movilidad interna de los extranjeros, también apuntan a cómo las diferencias de género afectan a la movilidad de determinados orígenes nacionales y cómo los factores individuales influyen de manera similar en todos los países analizados.

Pumares, García y Asensio ${ }^{12}$ relacionan en su investigación la migración interior de los extranjeros en España a partir de los datos de la Estadística de Variaciones Residenciales con las estadísticas de extranjeros en alta laboral en la Seguridad Social. De acuerdo con su análisis, el cambio de lugar de residencia de los extranjeros, con un comportamiento diferente al de los autóctonos - mayor tasa de movilidad y movilidad a lugares más lejanos de los primeros frente a los segundos- es una estrategia necesaria para "mantenerse ocupados con un salario como única manera de

\footnotetext{
6 Recaño, 2002

7 Recaño, 2002, p. 135

8 Recaño, 2016, p. 49

9 Recaño y Domingo, 2006

10 Recaño y Domingo, 2006, p. 291

11 Recaño y De Miguel (2012)

12 Pumares, García y Asensio, 2006
} 
sobrevivir y la voluntad de mejora en las condiciones de vida y trabajo"13. Además, este comportamiento diferencial se debe a la reciente llegada de la mayoría de los extranjeros y cuestionan que la presencia de compatriotas en un determinado lugar sea un factor clave para explicar su movilidad o, lo que es lo mismo, la migración interna no "refuerza la concentración de los inmigrantes", frente a factores con mayor impacto como el "acceso más fácil -más económico- a la vivienda" y la "percepción de mejores oportunidades laborales" o la posibilidad de encontrar trabajo o mejorar las condiciones laborales" ${ }^{\prime 14}$.

Varias investigaciones han profundizado en las consecuencias de la crisis económica que comenzó en 2008 en España sobre las pautas de la movilidad interna de la población extranjera. Sabater, Bayona y Domingo ${ }^{15}$ analizan la correlación entre la bajada de la tasa de movilidad y la tendencia hacia la aceleración de la formación de enclaves de migrantes -enclaves étnicos y/o concentraciones residenciales propias y aisladas-, llegando a la conclusión de que no se puede generalizar pues depende de cada grupo concreto de migrantes, a pesar de que la interpretación dominante sea que la crisis económica provoca la emergencia de nuevas pautas de asentamiento que manifiestan una severa exclusión social. Por su parte, Gil, Bayona y Pujadas ${ }^{16}$ constatan también el descenso de la importancia en términos absolutos y relativos de las migraciones internas de los extranjeros, aunque "pese a la crisis, los extranjeros, con 77 migraciones internas por cada mil habitantes de dicho origen, cambiaron de residencia en 2011 muchas más veces que los autóctonos, con sólo 29 cambios de residencia por cada mil españoles" ${ }^{17}$. La "estrategia de menor movilidad" se debe a la imposibilidad de una mejora significativa de las perspectivas"18. Los autores también señalan cambios tanto en las tasas de movilidad interna de cada nacionalidad como en las provincias de emisión y recepción de la misma, y concluyen que:

el menor número de migraciones (tanto internacionales como internas), la redistribución de los migrantes extranjeros desde las provincias más afectadas por el pinchazo de la burbuja inmobiliaria hacia las provincias que cuentan con porcentajes de extranjeros más bajos, y una cierta estabilidad -o fijación- residencial en comparación a la etapa anterior a 2008, parecen ser los efectos más significativos de la crisis en materia migratoria, aunque su profundidad e impacto sobre la población extranjera hacen prever nuevos cambios en los años futuros ${ }^{19}$.

Finalmente García, López y Pujadas ${ }^{20}$ se centran en el análisis de un estudio de caso (la migración intrametropolitana de la Región Metropolitana de Barcelona) que incluye entre sus objetivos "el análisis diferenciado según la edad de los migrantes y según se trate de españoles o extranjeros", para concluir en "la incidencia desigual

13 Pumares, García y Asensio, 2006, p. 204

14 Pumares, García y Asensio, 2006, p. 205

15 Sabater, Bayona y Domingo, 2012

16 Gil, Bayona y Pujadas, 2015

17 Gil, Bayona y Pujadas, 2015, p. 257

18 Gil, Bayona y Pujadas, 2015, p. 255

19 Gil, Bayona y Pujadas, 2015, p. 258

20 García, López y Pujadas, 2016 
de la crisis tanto desde el punto de vista de las características territoriales (compacto/disperso) como de las personas (adultos-jóvenes, mayores o extranjeros)"21.

La movilidad residencial de los extranjeros es extraordinariamente intensa y contrasta en gran medida con la de los españoles. Sus tasas de migración intrametropolitana aumentan espectacularmente hasta el año 2006 -cuando alcanza su máximo valor $(85,7 \%$ o $)$ - y se sitúa en todo momento en valores muy superiores a los de los españoles. La llegada reciente de la mayoría de población extranjera y la provisionalidad relacionada con las primeras etapas de asentamiento, tanto residencial, laboral o de consolidación familiar explica, en parte, esa mayor movilidad que se extiende a lo largo de todas las edades activas y no sólo en el momento de formación familiar (...) A partir de 2006, la tasa de migración desciende hasta alcanzar el $66 \%$ en 2011 , momento en el que la movilidad de los españoles se situaba en un $21 \%$ (...) La desigual situación [laboral] convierte a los extranjeros en un colectivo más vulnerable en el panorama social actual y, en último término, también tiene su incidencia frenando movilidad residencial. Migraciones vinculadas a una mejora laboral o de la vivienda, siguiendo el proceso de suburbanización iniciado también por los extranjeros en la etapa anterior, se verían así debilitadas en esta etapa de coyuntura económica desfavorable ${ }^{22}$.

En la mayoría de las investigaciones anteriores, el caso chino no aparece explícitamente; o es uno más entre otros o se diluye incluido dentro de la categoría asiáticos. Una de las características de su movilidad interna en España (intra-municipal, intra-metropolitana, inter-municipal, intra-provincial e inter-provincial) es que sus tasas suelen encontrarse entre las más elevadas en comparación con las del resto de los extranjeros de otros orígenes tal y como ponen de manifiesto las siguientes citas:

Entre los asiáticos, los ciudadanos chinos y pakistaníes presentan los niveles más elevados de movilidad, con valores significativamente superiores a filipinos e hindúes (...) Predomina la movilidad masculina en hindúes y paquistaníes, la femenina entre los filipinos y la de componente familiar entre los ciudadanos chinos ${ }^{23}$.

Entre las nacionalidades con más efectivos en Barcelona, chinos, pakistaníes y marroquíes son, por este orden, los que presentan una intensidad de la movilidad residencial más elevada. En el periodo 2006-2008, 2 de cada 10 chinos han abandonado anualmente Barcelona, mientras que pakistaníes y marroquíes presentan una tasa bruta ligeramente inferior. Estas tres mismas nacionalidades muestran una evolución reciente específica: los chinos cambian de residencia cada vez con más intensidad, los pakistaníes han reducido la extraordinaria intensidad con la que cambiaron de residencia en 2005, mientras que la intensidad de los marroquíes es estable desde $2004^{24}$.

Entre los chinos, también se observa una fuerte preferencia por la localización en los municipios limitrofes, aunque de una forma más moderada que entre la población pakistaní. En su caso, casi la mitad de las salidas trasladan su residencia a los municipios de SantaColoma de Gramenet y Badalona ${ }^{25}$.

Indicador Sintético de Migración interna (ISMi), cuyo resultado nos indicaría el número de cambios migratorios internos que se realizarían a lo largo de una vida si se mantuvieran las tasas observadas en el año estudiado. Los resultados obtenidos nos indican que los españoles, con independencia del sexo, realizarían 2,5 cambios de municipio a lo largo de su vida con las

21 García, López y Pujadas, 2016, p. 3

22 García, López y Pujadas, 2016, p. 14

23 García, López y Pujadas, 2016, p. 14

24 Bayona y López-Gay, 2011, pp. 400-401

25 Bayona y López-Gay, 2011, pp. 406 
tasas observadas en 2011, valor que para los extranjeros se dobla, con justo 5 movimientos. Éstos, por grupo continental, oscilan entre el mínimo de los europeos ( 3 para los hombres y 3,3 para las mujeres) y el máximo de los asiáticos $(9,9$ y 8,1), pasando por los valores de africanos $(7,9$ y 6,8$)$ y americanos $(6,5$ y 7,2$)$. Con este indicador se observa la alta intensidad de las migraciones internas de algunos colectivos ${ }^{26}$.

En la RMB [Región Metropolitana de Barcelona], las tasas son en general muy elevadas y superiores a las que las mismas nacionalidades presentan en la CAM [Comunidad Autónoma de Madrid]. Las nacionalidades asiáticas (chinos, indios y pakistaníes) y algunas latinoamericanas (bolivianos, dominicanos y colombianos) son las que presentan las mayores intensidades relativas en la RMB, siempre superando tasas del cien por mil. En algunos casos concretos (ecuatorianos o chinos) incluso presentan el doble de intensidad migratoria en la RMB que en la CAM (p. 41). Por nacionalidades, los chinos -sólo superados por los indios en la RMB- son los que presentan de nuevo una movilidad interna más acentuada tanto en la CAM como en la RMB, aunque con un ISM [Indice Sintético de Movilidad] que es un 50\% más elevado en la conurbación catalana ${ }^{27}$.

Las investigaciones anteriores analizan la evolución o la situación concreta de la localización geográfica del asentamiento de los extranjeros en España en distintos momentos. De los asiáticos, y en ocasiones con referencia concreta a los chinos, se afirma que tienen una elevada tasa de cambio de residencia intraurbana y entre municipios y provincias. Por otra parte, también se constata la aparición de diversas concentraciones residenciales en las grandes ciudades y sus zonas metropolitanas en investigaciones generales y en las centradas específicamente en el análisis de la migración china en España ${ }^{28}$.

Beltrán Antolín ${ }^{29}$ ya señalaba la aparición de ciertas concentraciones de residentes chinos en España. El mismo autor comparaba Madrid y Barcelona en ese comportamiento entre 2005 y 2009, al igual que profundizaba en este aspecto en Cataluña y Barcelona ${ }^{30}$. Beltrán Antolín y Sáiz López ${ }^{31}$ analizan las características del trabajo y de la pequeña empresa familiar china en España que tienen consecuencias en sus pautas residenciales. En este mismo sentido, varios investigadores han trabajado sobre el empresariado migrante o étnico en España destacando determinadas concentraciones de empresarios extranjeros en barrios concretos de ciudades: Serra $^{32}$ afirma que procesos como la concentración o dispersión, diversidad o especialización, mono etnicidad o multietnicidad, da lugar a espacios de negocios étnicos a

26 Gil, Bayona y Pujadas, 2015, p. 249

27 Bayona, Gil y Pujadas, 2013, p. 42

28 Aunque el objetivo de este artículo no es el análisis del fenómeno de las concentraciones residenciales de migrantes chinos conocidas como "Chinatown", cabe mencionar que han sido ampliamente investigadas en todo el mundo desde diferentes perspectivas, como la construcción social de un imaginario (Anderson, 1991; Bildimeier, 2011), o su transformación en espacios turísticos (Yamashita, 2003), o la aparición de nuevas concentraciones residenciales con características diferentes a las originales (Fong, 1994; Li, 1998). Veáse por ejemplo obras sobre este fenómeno a escala regional y global: Christiansen, 2003; Thuno, 2007; Künnemann y Mayer, 2011; Wong y Tan, 2013; McDonogh, 2013; Wong y McDonogh, 2013; Sanjuan, 2017.

29 Beltrán Antolín, 2000

30 Beltrán Antolín, 2009b

31 Beltrán Antolín y Sáiz López, 2006, 2009, 2013, 2015

32 Serra, 2009 
los que denomina "centralidades étnicas". El mismo autor, en $2011^{33}$ complejiza el marco del "enclave étnico" a partir de la constatación de diversos procesos de descentralización de residentes inmigrantes hacia la periferia urbana, la dispersión geográfica de los emprendedores de un mismo origen étnico, y la convivencia de múltiples grupos étnicos en una misma zona o barrio. Miret y Serra ${ }^{34}$ muestran cómo la presencia residencial de extranjeros y la implantación de comercios regentados por emprendedores inmigrantes en ciertos barrios -su estudio de caso es el barrio de el Besòs i el Maresme de la ciudad de Barcelona- impulsa el cambio y la revitalización urbanística. En la muestra que analizan de comercios regentados por extranjeros el $22 \%$ corresponde a residentes chinos.

Investigaciones más recientes han abordado las pautas residenciales de los chinos en Madrid ${ }^{35}$, donde se analiza su organización espacial, social y económica, especialmente en su concentración residencial y de negocios en el barrio de Usera, y en Barcelona ${ }^{36}$. Estos últimos trabajos incluyen la referencia a "Chinatown" -en sentido geográfico-, aunque sea para cuestionarla y se hacen eco de la inversión de capital chino en el mercado inmobiliario español.

Las mayores concentraciones residenciales de población china en España, aparte de su presencia en polígonos industriales, se encuentran en Santa Coloma de Gramanet (municipio del área metropolitana de Barcelona) donde había 23.5 17 extranjeros empadronados a 1 de enero de 2017 (el 19,7\% del total de la población), de los cuales 4.870 eran chinos (representando al 20,7\% del total de los extranjeros en la ciudad). En el año 2017 en el Distrito VI (conocido popularmente como el barrio de Fondo, que limita con la ciudad de Badalona donde también el volumen de población china es significativo) de una población total de 16.673 habitantes, el 17,4\% era china (2.909 empadronados, lo que representaba el 42,4\% del total de los vecinos extranjeros en el barrio). Por su parte en Madrid, en el distrito de Usera a 1 de enero de 2017 había 25.866 extranjeros empadronados (19,24\% del total de la población del distrito) de los cuales 7.988 eran chinos, es decir la tercera parte de todos los extranjeros del distrito y casi la cuarta parte de todos los chinos de Madrid que en total eran 35.422. Además de estas dos concentraciones residenciales específicas, en las que en ningún caso constituyen la mayoría de la población de los barrios, tanto en la ciudad de Barcelona como en la de Madrid hay otros espacios que en algún momento han sido denominados "Chinatown" por la visibilidad de la presencia de sus negocios: el barrio de Lavapiés en Madrid y Fort Pienc en el Eixample de Barcelona. Aunque no siempre la concentración de negocios chinos implica una concentración residencial. Tanto en Madrid como en Barcelona, y en muchas otras capitales de provincia de España, se ha producido una presión pública y de los gobiernos locales para que determinados negocios (tiendas de venta al por mayor, empresas de importación/exportación) se trasladaran a la periferia metropolitana, a polígonos

33 Serra, 2011

34 Miret y Serra, 2013

35 Tébar, 2011

36 Martínez-Rigol et al, 2017; Bernardos et al, 2014 
industriales, dando lugar a importantes concentraciones de negocios chinos en el polígono Cobo Calleja de Fuenlabrada (área metropolitana de Madrid), el polígono Sud de Badalona (área metropolitana de Barcelona) y en otros polígonos industriales de capitales de provincia españolas.

En definitiva, el estado de la cuestión sobre el comportamiento chino en la migración, movilidad y vivienda en España remite a una elevada movilidad interna, al mismo tiempo que ha dado lugar a unas pocas y pequeñas concentraciones residenciales en las grandes ciudades y sus zonas metropolitanas que han llamado la atención a la opinión pública que ha recurrido al anglicismo "Chinatown" para referirse a ellas. Los motivos para explicar este comportamiento están directamente relacionados con las características de su trabajo y las actividades económicas desarrolladas, y con los cambios en las mismas a lo largo del tiempo de su estancia y asentamiento, tal y como se analizará en los siguientes apartados.

\section{Vivienda y trabajo: de la emergencia a la estabilidad}

La carrera o trayectoria residencial de la población en relación al ciclo de vida personal ha sido ampliamente analizada por autores como Clark y Huang ${ }^{37}$, quienes señalan el vínculo entre el consumo de espacio de vivienda y el cambio de estatus de solteros a casados y a tener hijos, por ejemplo. La necesidad de espacio para vivir aumenta conforme se forman nuevos núcleos familiares y se incrementa su tamaño. En este mismo sentido, existen otros estudiosos que revisan la cuestión y profundizan en el tema. Por ejemplo, Coulter y van $\mathrm{Ham}^{38}$ tratan de superar las limitaciones del marco de las trayectorias vitales en los estudios longitudinales que vinculan la toma de decisión de la movilidad residencial al consiguiente comportamiento de movimiento a corto plazo y para ello introducen la secuenciación a largo plazo del deseo de cambio y el comportamiento de la movilidad dentro de las vidas de los individuos. En esta aportación resalta la estabilidad residencial a lo largo de la vida, descubriendo grupos de individuos incapaces de actuar de acuerdo con sus deseos de mudanza. Coulter, van Ham y Findlay ${ }^{39}$, a partir del enfoque del ciclo de vida, proponen un nuevo marco conceptual para la investigación de "la movilidad e inmovilidad residencial que deben ser reconceptualizadas como prácticas relacionales que vinculan vidas, al mismo tiempo que conectan a las personas con las condiciones estructurales, a través del tiempo y el espacio ${ }^{40 \prime}$. Pereira, Fringe y Ferreira en su análisis sobre las trayectorias residenciales en el Area Metropolitana de Lisboa llegan a la conclusión de que "Lisboa es el primer lugar donde se instalan los inmigrantes, y su progresiva integración en la sociedad local los lleva a la periferia, donde tienden a vivir más como los 'autóctonos', tanto en términos de su vida familiar como de sus condiciones de vivienda"41.

37 Clark y Huang, 2003

38 Coulter y van Ham, 2013

39 Coulter, van Ham y Findlay, 2016

40 Coulter, van Ham y Findlay, 2016, p. 367

41 Pereira, Fringe y Ferreira, 2014, p. 17 
Pereda, Actis y Prada ${ }^{42}$ realizaron un estudio concreto sobre la relación entre inmigración y vivienda donde analizaban, entre otras cosas, la evolución residencial -trayectoria o carrera residencial- y los cambios que conlleva desde la llegada de los migrantes hasta el momento que en alcanzan su estabilidad residencial. Las primeras viviendas son de emergencia y se comparte piso con otras personas que pueden ser familiares o amigos o los empleadores. Esta estrategia residencial supone un ahorro del coste del alojamiento durante la primera fase de la trayectoria migratoria. Las viviendas de transición en muchos casos pasan por la subcontratación de alquileres o subarriendos. Durante esta fase, no desaparecen todavía las viviendas de emergencia. El último eslabón se caracteriza por una mayor estabilidad. Esta estabilidad incluye también alojamientos de transición, pero se pasa al alquiler independiente o a la compra. El coste del alojamiento es mayor que en las fases de emergencia y transición y comienza la residencia de familias completas en viviendas individuales.

Otros investigadores como Fullaondo ${ }^{43}$, coinciden en la división de la trayectoria residencial de los migrantes en tres etapas: llegada, asentamiento y estabilización. Por su parte García y Frizzera ${ }^{44}$ añaden a las anteriores la del "aterrizaje", señalando que:

Cada etapa presenta diferencias en los criterios de localización residencial; en el tipo de vivienda al que el inmigrante aspira; y en la composición del hogar. Asimismo, las etapas evolucionan de acuerdo con el origen del inmigrante, su capital humano, su acceso a redes sociales y según si su proyecto migratorio es individual o familiar ${ }^{45}$.

En la etapa inicial de residencia en España, los migrantes chinos procedentes del sur de la provincia de Zhejiang se caracterizan por un cambio de vivienda continuo que va disminuyendo con los años conforme adquieren una mayor estabilidad laboral, económica y familiar.

Inicialmente, viven en "alojamientos de emergencia", como por ejemplo casas de familiares o amigos. Aunque esta es la opción más habitual, hay otras como vivir en el mismo local donde se trabaja. En algunos casos los locales comerciales donde se alojan no están habilitados como vivienda. Es una estrategia para ahorrar el dinero que se debería de gastar en el alquiler o la compra de una vivienda. Este tipo de comportamiento residencial de "emergencia" se ha llevado a cabo en ocasiones en restaurantes de comida china y, especialmente, en algunos talleres de confección. El trabajo en la confección apareció durante la década de 1990 como una alternativa laboral en un nuevo nicho económico étnico desarrollado para proporcionar empleo a la mano de obra disponible procedente de China que no podía absorber los otros negocios de su propiedad. El trabajo en los talleres de confección siempre fue temporal y se asociaba a una parte de los recién llegados que no tenían otra al-

42 Pereda, Actis y Prada, 2005

43 Fullaondo, 2008

44 García y Frizzera, 2008

45 García y Frizzera, 2008, p. 39 
ternativa. Este sector se caracterizaba por una hipermovilidad de la mano de obra ${ }^{46}$. Algunos de estos talleres se encontraban en los mismos pisos donde vivían -y no en locales destinados a servicios o producción-, siguiendo una práctica habitual de la economía informal local donde la población autóctona hacía lo mismo -trabajo en economía sumergida donde el lugar de producción es la misma vivienda donde se reside.

La Brigada Provincial de Documentación ha descubierto en Madrid tres talleres clandestinos de confección de ropa en los que trabajaba ilegalmente un grupo de 29 ciudadanos de origen chino. Entre los extranjeros había algunos que tenían una jornada laboral de 12 horas de duración y comian y dormían en los propios centros de producción ${ }^{47}$.

La Policía ha clausurado en Málaga un taller clandestino de confección textil en el que explotaban a ciudadanos de nacionalidad china, que pernoctaban en el interior del local, el cual carecía de medidas de seguridad. El taller estaba ubicado en un local comercial situado en los bajos de un inmueble del barrio de Huelin de la capital malagueña, y distribuido en dos plantas, una de ellas utilizada como área de trabajo y con tres dormitorios, y la otra como almacén, con cocina y duchas, según informó hoy la Comisaría Provincial de Policía en un comunicado ${ }^{48}$.

La Policía Local de Brunete, han detenido a una empresaria textil que hacinaba a 44 trabajadores en dos talleres de la localidad madrileña de Brunete (...) utilizaba la parte superior de uno de los talleres como hostal para alquilar habitaciones a sus trabajadores (...) los ciudadanos chinos apenas salían a la calle puesto que la parte superior de uno de los talleres estaba habilitada como hostal, cuya titular era también la persona arrestada. ${ }^{49}$

El subarriendo es una práctica habitual en la fase de transición residencial. El alquiler de una habitación en un piso compartido a veces provoca fenómenos de hacinamiento. Normalmente quien alquila son jóvenes solos, aunque en ocasiones en una habitación puede vivir una pareja casada e incluso con hijos. Si se recurre al subarriendo es igualmente para ahorrar en los gastos dedicados al alojamiento, porque las expectativas de los migrantes chinos son ahorrar el capital suficiente para, en primer lugar, abrir sus propios negocios y, posteriormente adquirir viviendas. Con este objetivo reducen los gastos de consumo -incluidos los gastos en vivienda- al mínimo. Una forma de ahorrar es compartir piso con otros migrantes y/o subarrendar habitaciones. Los arrendadores, a su vez, suelen ser también migrantes chinos que, de este modo, obtienen ingresos económicos adicionales.

Es habitual entre los migrantes de todos los orígenes intentar residir cerca del lugar de trabajo para ahorrar en costes de transporte. Esta circunstancia es dominante en el comportamiento residencial chino en España. Por eso, cuando se cambia de trabajo, se suele cambiar también de residencia con el objetivo de vivir en la proximidad de donde se trabaja. Una peculiaridad de la migración china es que los empleadores -chinos- en ocasiones ofrecen alojamiento a sus empleados.

De hecho, este comportamiento es similar a como han funcionado las relaciones

46 Beltrán Antolín y Sáiz López, 2006, 2009

47 Duva, 1991

48 EFE, 2007

49 Hidalgo, 2013 
Alojamientos de emergencia:

casas de familiares 0

amigos, lugar de trabajo
Alojamientos estables:

alquiler independiente 0

compra

\section{Alojamiento de transición:}

subarriendo

Figura 1. Fases residenciales

Fuente: elaboración propia

laborales en la China urbana antes de las reformas económicas del país (1978) y que se han reproducido posteriormente en la industrialización rural. Las industrias privadas abiertas en las zonas rurales desde la década de 1980 suelen ofrecer alojamiento a sus trabajadores en residencias que se encuentran en el mismo lugar de trabajo, de forma parecida a la "colonias industriales" de España. El caso extremo es el de los trabajadores de la construcción que viven en el mismo lugar donde trabajan, en barracones que proporcionan las empresas de construcción. La organización laboral y residencial urbana en China se estructuraba a partir de las danwei (unidades de trabajo) ) $^{50}$ toda la población urbana estaba asignada a una "unidad de trabajo", la cual proporcionaba además de trabajo, todos los servicios de la sociedad de bienestar socialista, incluida la vivienda. El trabajador sólo pagaba un precio simbólico de alquiler y toda la vivienda urbana era pública. En definitiva, el empleador proporcionaba alojamiento "gratuito" al trabajador, y las industrias rurales privadas actualmente hacen lo mismo, aunque en este caso el coste del alojamiento se descuenta de los salarios. Este tipo de arreglo residencial se reproduce en España, llegando incluso a que los trabajadores vivan en la misma casa que el empleador.

\section{Adquisición de vivienda para residencia y/o inversión}

La fase de la estabilidad residencial se caracteriza por el acceso a una vivienda propia donde reside toda la familia, sea en régimen de alquiler o de propiedad. Lo más habitual es el régimen de alquiler y sólo quiénes han sido capaces de prosperar con su trabajo y negocios por encima de la media, con el paso del tiempo y la disponibilidad de suficientes recursos económicos, invierten en la compra de vivienda para ser propietarios de las mismas. En el momento en que se decide iniciar el proceso de la reunificación familiar es necesario disponer de una vivienda en alquiler o propie-

50 Bray, 2005 
dad que reúna los requisitos de habitabilidad exigidos para obtener el permiso. De este modo, se alquilan viviendas para uso familiar como condición necesaria para que toda la familia pueda vivir junta.

Estas viviendas unifamiliares pueden convertirse a su vez en alojamientos de emergencia para parientes más lejanos, amigos y conocidos recién llegados que ocuparán alguna habitación, o para aquellos a quienes se ha ayudado a llegar a España para que sean mano de obra en sus propios negocios; o algunas de sus habitaciones pueden llegar a subarrendarse a otros migrantes chinos con el objetivo de conseguir ingresos extra.

Aquellos que ya disponen de vivienda en propiedad, además de mayores recursos económicos, pueden decidir comprar nuevas viviendas que dedicarán a alquilarlas en su totalidad, bien sea a largo plazo o a corto plazo para viajeros y turistas (tipo airbnb). Su objetivo también es obtener más ingresos.

Tabla 1. Compra de viviendas por chinos en España. Años 2006-2017

\begin{tabular}{lrrr}
\hline Año & $\begin{array}{r}\text { Compra vivienda por } \\
\text { chinos }\end{array}$ & $\begin{array}{r}\text { \% chinos de compra } \\
\text { por extranjeros }\end{array}$ & $\begin{array}{r}\text { China frente a otros } \\
\text { orígenes extranjeros }\end{array}$ \\
\hline 2006 & 306 & 1,28 & 14 \\
2007 & 935 & 1,62 & 12 \\
2008 & 631 & 2,08 & 11 \\
2009 & 427 & 2,59 & 10 \\
2010 & 759 & 4,09 & 9 \\
2011 & 813 & 3,88 & 9 \\
2012 & 1.703 & 4,30 & 9 \\
2013 & 1.120 & 3,06 & 10 \\
2014 & 1.530 & 3,67 & 9 \\
2015 & 1.843 & 3,97 & 7 \\
2016 & 2.214 & 4,14 & 8 \\
2017 & 2.672 & 4,38 & \\
\hline Total & $\mathbf{1 4 . 9 5 3}$ & & \\
\hline
\end{tabular}

Fuente: Elaboración propia a partir de la Estadística Registral Inmobiliaria

La distribución geográfica de sus compras por Comunidades Autónomas se explica por sus características en el mundo laboral. En concreto, por su expectativa convertida en realidad de ser empresarios de pequeños negocios familiares de servicios. En su búsqueda de nuevas clientelas para sus negocios se dirigen a zonas de España donde la presencia de la población china es menor. La excepción a este fenómeno es Madrid, donde en el año 2016 realizaron el 19\% de todas las compras de vivienda por extranjeros en esa Comunidad Autónoma y donde además reside 
también la cuarta parte de toda la población china en España.

En la Tabla 2 se observa que las comunidades autónomas con menos residentes de origen chino y una historia más corta de su asentamiento son las que cuentan con una proporción más elevada de trabajadores autónomos chinos: Asturias (72,7\% autónomos), La Rioja (72,6\%), Navarra (69,4\%), Castilla-León (67\%), Aragón $(66,3 \%)$, Murcia (66,1\%), Galicia (65,3\%), Extremadura (61,8\%), Cantabria $(61,8 \%)$. La explicación de este fenómeno es que los chinos cambian de residencia para abrir nuevos negocios y van a los lugares donde la presencia china es menor para tener menos competencia entre ellos en los sectores donde se han insertado y cuyo funcionamiento conocen bien: primero fueron los restaurantes de comida china, después los bazares, tiendas de ropa y zapaterías, peluquerías y el traspaso de bares autóctonos, etc. ${ }^{51}$

En Madrid y Cataluña han alcanzado el punto de saturación y entonces, una vez disponen del capital para establecer nuevas empresas en los sectores que ya conocen, buscan lugares y ciudades donde poder prosperar y tener éxito, es decir, donde todavía hay "pocos" chinos residentes. Y allá donde van y se establecen compran y/o alquilan viviendas y locales para alojarse y desarrollar sus negocios.

Aunque a nivel global los chinos ocupan la octava posición en el ranking de extranjeros que compran vivienda en España en 2016, en muchas comunidades autónomas se encuentran en una posición más alta en cuanto a viviendas compradas frente al volumen de población en relación al total de extranjeros. Por ejemplo, en Cantabria son la novena comunidad extranjera con más población, pero suben hasta el tercer puesto en cuanto a compra de vivienda se refiere. En Galicia también son los terceros en volumen de compra frente a ocupar la séptima posición por nacionalidad extranjera.

Los residentes chinos han comprado de 2006 a 2017 un total aproximado de 14.953 viviendas en España de acuerdo a los datos que proporciona la Estadística Registral Inmobiliaria. Durante este periodo de tiempo han pasado de ocupar la posición catorceava de todos los extranjeros que compran vivienda en España a la octava, detrás de Reino Unido, Francia, Alemania, Bélgica, Suecia, Italia y Rumanía. El año 2017 los chinos compraron el 4,38\% de todas las viviendas compradas por extranjeros, alcanzado el mayor porcentaje del periodo que no ha dejado de crecer desde 2013.

Finalmente hay otro tipo de residente chino que ha obtenido su permiso de residencia gracias a la Ley 14/2013 de Apoyo a los Emprendedores y su Internacionalización al invertir por valor de 500.000 euros en la compra de bienes inmuebles en España. Los últimos datos disponibles de finales del año 2017 indican que, de los 12.578 extranjeros que han obtenido la residencia por diversos motivos de interés económico que permite la ley (profesional altamente cualificado, traslados intra-empresariales, investigadores, emprendedores e inversores), 1.848 fueron chinos (14,7\% del total). Del total de los inversores extranjeros (2.905), quienes en su

51 Beltrán Antolín y Sáiz López, 2015 
mayoría han invertido en la compra de bienes inmuebles, 997 son chinos (34,3\% de todos los inversores extranjeros), seguidos por 797 rusos $(27,4 \%)$.

Tabla 2. Compra vivienda de chinos en España por Comunidades Autónomas. Año 2016

\begin{tabular}{|c|c|c|c|c|}
\hline $\begin{array}{l}\text { Comunidad } \\
\text { Autónoma }\end{array}$ & $\begin{array}{r}\text { Chinos en \% } \\
\text { del total de } \\
\text { compradores } \\
\text { extranjeros }\end{array}$ & $\begin{array}{r}\text { Posición de } \\
\text { chinos con } \\
\text { respecto a otros } \\
\text { extranjeros en } \\
\text { la compra de } \\
\text { vivienda }\end{array}$ & $\begin{array}{r}\text { Posición chinos } \\
\text { con respecto } \\
\text { a permisos de } \\
\text { residencia de } \\
\text { nacionalidades } \\
\text { extranjeras }\end{array}$ & $\begin{array}{r}\text { Autónomos en } \\
\% \text { del total de } \\
\text { chinos afiliados } \\
\text { Seguridad } \\
\text { Social }\end{array}$ \\
\hline Aragón & $13,08 \%$ & 2 & 4 & 65,3 \\
\hline Asturias & $6,40 \%$ & 3 & 6 & 72,3 \\
\hline Baleares & $1,87 \%$ & 9 & 10 & 42,9 \\
\hline Canarias & $2,10 \%$ & 9 & 5 & 40,0 \\
\hline Cantabria & $6,98 \%$ & 3 & 9 & 59,5 \\
\hline Castilla y León & $4,95 \%$ & 4 & 6 & 64,2 \\
\hline $\begin{array}{l}\text { Castilla- } \\
\text { La Mancha }\end{array}$ & $4,56 \%$ & 3 & 6 & 58,3 \\
\hline Cataluña & $8,09 \%$ & 2 & 4 & 48,6 \\
\hline Extremadura & $5,88 \%$ & 2 & 4 & 59,3 \\
\hline Galicia & $5,71 \%$ & 3 & 7 & 63,0 \\
\hline Madrid & $18,89 \%$ & 2 & 3 & 47,0 \\
\hline Navarra & $4,00 \%$ & 6 & 8 & 68,6 \\
\hline País Vasco & $12,98 \%$ & 2 & 4 & 54,8 \\
\hline
\end{tabular}

Fuente: Elaboración propia a partir de Estadística Registral Inmobiliaria. Anuario 2016 y Extranjeros Residentes en España. A 31 de diciembre de 2016. Ministerio de Empleo y Seguridad Social (marzo 2016)

Las expectativas del gobierno español de vender viviendas a extranjeros a cambio de concederles el permiso de residencia no se han cumplido todavía, pues otros países que han aprobado normativas semejantes han tenido mucho más éxito, por ejemplo la vecina Portugal. Los chinos que obtienen la residencia en España mediante sus inversiones en bienes inmuebles constituyen un nuevo segmento de la población china en España constituido por una clase media alta y por ricos cuya motivación para conseguir la residencia incluye desde asegurar una parte de su capital en el extranjero a tener facilidad para moverse por el territorio Schengen, o la educación de sus hijos, la huida de un medioambiente muy contaminado en muchas ciudades chinas y la búsqueda de un espacio con mejor calidad de vida. También la posibilidad de expandir sus negocios de China ${ }^{52}$. Muchos de estos nuevos

52 Liu-Farrer, 2016 
residentes en realidad no residen en España y alquilan las viviendas que han comprado para obtener ingresos.

Además de estos inversores individuales, también ha llegado a España recientemente el gran capital chino de empresas multinacionales que invierte en bienes inmuebles, entre otras cosas. En 2017 había aproximadamente 98 multinacionales chinas establecidas en España. El 35,2\% de la IED bruta acumulada china en España durante 1993-2017 se encontraba en "actividades inmobiliarias" (1.435,13 millones de euros en total), siendo el segundo sector después del "suministro de energía eléctrica y gas" $(41,6 \%) 53$. Estas inversiones incluyen la compra de hoteles, por ejemplo.

\section{La procedencia de capital: ahorro y préstamos}

Las fuentes del capital para invertir en vivienda proceden fundamentalmente del ahorro de los trabajadores y empresarios que en su vida cotidiana reducen los gastos de consumo al máximo, al menos durante la primera fase de asentamiento, cuando recurren a viviendas de emergencia para su alojamiento, entre otras prácticas. Si llegado el momento de comprar una vivienda, el capital acumulado mediante el ahorro no es suficiente entonces solicitan préstamos a familiares, amigos y conocidos $y$, en última instancia, a instituciones financieras. En general, se prefiere pagar al contado el precio de la vivienda siempre que sea posible, aunque las hipotecas en los bancos también son habituales.

Al comienzo de su establecimiento en España cuentan con unos recursos económicos mínimos procedentes de sus ahorros de China. Nada más llegar a España comienzan a trabajar y con los primeros ingresos que obtienen se dedican a pagar las deudas contraídas para su llegada, en caso de que se hubieran endeudado para emigrar. A partir del pago de las deudas comienza el ahorro con el objetivo fundamental de abrir una empresa familiar y, en segunda instancia, comprar una vivienda. También se invierte en la construcción, rehabilitación y compra de vivienda en China si sus ingresos se lo permiten. Los migrantes que tienen éxito en el extranjero lo demuestran en China con la adquisición de viviendas nuevas ${ }^{54}$.

Los préstamos pueden tener distintos orígenes. El preferente es el proporcionado por los familiares y amigos, especialmente por los miembros más cercanos de las redes sociales de los migrantes que se encuentran en mejor posición económica. La primera opción son los conocidos y familiares que también residen en España $y$, si no es posible, se recurre a familiares en otros países europeos o de China directamente. No obstante, la llegada de capital procedente de China afronta muchas dificultades y supone un coste considerable, por lo que es la última opción. El capital prestado por las redes sociales se debe devolver, pero los plazos son flexibles y los intereses a menudo no existen, por lo que recurrir a ellos es mucho más competitivo que hacerlo entidades financieras. Otra estrategia para conseguir capital es la

53 Carril-Caccia y Milgram-Baleix, 2017, p. 124

54 Beltrán Antolín, 2004; Sáiz López, 2013 
creación de "grupos de ahorros" (biaohui o huzhuhui)..$^{55}$ Las fuentes de capital son diversas y se pueden combinar, es decir, la persona que necesita una cierta cantidad de dinero puede recurrir a diferentes fuentes a la vez.

\section{Trayectorias migratorias residenciales}

En este apartado se presentan varios testimonios de trayectorias residenciales de migrantes chinos que ayudan a completar el análisis y descripción anterior de la relación de los chinos con la movilidad y la residencia tanto en España como en China.

Mis abuelos se han quedado en China porque son mayores y no han querido mudarse a España ni cambiar el lugar de vida al que estaban acostumbrados. Viven en la casa donde vivíamos mis padres y yo. La vivienda fue construida por mi familia. Cada año vuelvo a China para visitarles, en general, durante las vacaciones de verano. Mis padres también quieren volver a China, pero no pueden debido a que tienen que cuidar el bar. Cada tres meses mis padres envían dinero a mis abuelos. Tengo un hermano menor que ahora está con mis abuelos. Cuando puedan, mis padres piensan traerlo a España. Aunque dejar a sus padres sin ver a su nieto les da mucha pena, ya que tampoco ven a sus hijos (Mujer, 19 años).

Hay miembros de la familia que no emigran y continúan viviendo en el mismo lugar y vivienda de siempre. Es frecuente que los migrantes envíen dinero a China para ayudar a estos familiares. Normalmente, los que se quedan son los ancianos y los niños. Esto hace que se mantenga el contacto estrecho entre ambos países, y disponen de un sitio donde residir en los dos lugares.

La vivienda que conservo en China es la casa de mis padres. Ellos la compraron hace años a su danwei (unidad de trabajo). Iba a estudiar a los colegios que estaban cerca de donde vivíamos. Después de unos años, la zona de mi barrio fue reconstruida y mis padres decidieron comprar una de las nuevas viviendas. Además, cerca de allí, se abrieron colegios privados. Estos colegios abarcan todos los cursos: desde la educación preescolar hasta el bachillerato. La gente que vive en el complejo residencial donde están esos colegios tiene el privilegio de tener una plaza reservada (Hombre, 27 años).

Los complejos residenciales en China son urbanizaciones construidas en las últimas décadas que ofrecen servicios de calidad además de vivienda. El acceso a una educación de calidad es un reclamo para vender estas nuevas viviendas y muchos las compran para obtener el $h u k o u^{56}$ en esa zona, lo que les asegura plazas en esos centros escolares para sus hijos.

55 Grupo cerrado de personas físicas y/o jurídicas con el fin de proporcionar la adquisición de bienes o recursos financieros por medio del autofinanciamiento entre sus miembros mediante la aportación de una cuota mensual por cada uno. El grupo de ahorros normalmente está formado por personas individuales que se conocen entre ellas y la mayoría provienen de la provincia de Fujian. En la provincia de Guangdong también históricamente ha sido una práctica habitual para obtener financiación.

56 El sistema hukou fue instaurado en 1951 para registrar la población y controlar su movilidad. El sistema se amplió en 1955 para cubrir tanto a la población rural como a la urbana (Mallee, 1988; Cheng y Selden, 1994). En 1958, la promulgación de un reglamento hukou de mayor alcance (hukou dengji tiaoli) estipuló la imposibilidad de cambiar del empadronamiento rural al urbano si no se tenía el permiso del gobierno. 
Antes tenía una danwei, trabajaba en Correos gracias a que mi padre también trabajó allí. Cuando él se jubiló, me dejó su puesto de trabajo (dingti). ${ }^{57}$ Durante varios años, estuve pagando el alquiler de la vivienda que me ofrecía mi danwei. Hasta 1994, tuve la opción de comprar esa misma vivienda, pero decidí no hacerlo. Dejé ese trabajo y empecé a trabajar por mi cuenta. Además, tampoco tenía suficientes ahorros para comprarla. Ahora, me he arrepentido de no haberlo hecho, porque, luego podría haberla vendido más cara y ganar dinero. En cualquier caso, invertí en una vivienda en España con el dinero que conseguí vendiendo una de mis antiguas propiedades en China. Así que, aunque no aproveché la oportunidad de la danwei, pude ganar dinero vendiendo esta vivienda por un precio más elevado que el que yo pagué (Hombre, 40 años).

A continuación, se muestra una trayectoria residencial donde queda clara la vinculación entre trabajo y residencia a lo largo del tiempo y donde se observa el paso de la fase de emergencia a la de estabilidad:

Mis padres llegaron hace 22 años a España, yo llevo menos, unos 13 años. Además, tengo dos hermanos que ya han nacido en España, aunque tienen su hukou en China. A lo largo de los años, hemos cambiado de casa seis veces. Mis padres, cuando llegaron a España, consiguieron un trabajo donde ofrecían alojamiento y comida, viviendo con otros compañeros. Después, se fueron a trabajar a una fábrica textil donde aprendieron el negocio y, por eso, decidieron cambiar de domicilio, ya que la fábrica estaba lejos de su anterior vivienda.

Unos años después, me trajeron a España y decidieron comprar una casa adosada en Mataró. Esta casa tiene cuatro plantas, incluyendo un sótano. Mis padres hicieron una reforma de esta planta y lo transformaron en una pequeña fábrica textil. Nosotros vivíamos en las plantas altas de la casa, yo vivía con mi prima. También vino una tía mía de China para ayudar en el negocio textil. Mis padres reformaron el salón, el garaje y la azotea, que es donde vivían los trabajadores. En los espacios reformados se utilizaron materiales temporales, como cortinas y paredes de pladur o de madera. Mis padres ofrecían alojamiento, comida y salario a los trabajadores que venían al taller textil y que tenían una situación irregular, así todos estaban bien y nadie se quejaba.

El negocio del taller se cerró el año 2008, debido a la crisis. Mis padres vendieron todas las máquinas y buscaron otro tipo de negocio. Al final, encontraron un restaurante en traspaso en Castellón y decidieron mudarse allí. Una vez que llegamos a Castellón, buscamos un piso temporal de alquiler. Al acceder a esta vivienda no fuimos muy exigentes, ya que sabíamos que nos acabaríamos yendo a otra casa. Pronto, encontramos otra vivienda, una casa adosada de la cual alquilamos dos plantas. Estábamos muy contentos con este domicilio. La planta baja estaba alquilada a un español que tenía un restaurante con el que hubo algún conflicto y finalmente decidieron buscar otro sitio donde vivir.

Ahora, el restaurante de mi familia funciona bien y hemos podido alquilar dos pisos. En uno vivimos mi familia y yo, y en el otro viven los trabajadores. Antes, cuando estaba de vacaciones, ayudaba a mis padres en el restaurante y ellos me pagaban algo también. Ahora, mi prima les ayuda en el restaurante porque yo decidí venir a Barcelona hace dos años para aprender peluquería. En Barcelona, al principio, vivía en casa de mi maestro, aunque ahora comparto piso con otras personas en la zona de Tetuán (Hombre, 25 años).

Una informante de la provincia de Fujian cuya familia ya tenía una vivienda en China, decidió comprar un piso nuevo allí, al mismo tiempo que otro en la ciudad

57 Dingti era una norma durante las décadas de 1970 y 1980 por la cual los empleos en empresas estatales de China de los padres se asignaban a sus hijos cuando ellos se jubilaban. A finales de los años ochenta desapareció esta práctica con el inicio de las reformas económicas en el país y la privatización de las empresas públicas. 
de Barcelona. Lo más relevante de la compra del piso en Barcelona es la procedencia del capital, ya que esta familia consiguió el dinero necesario gracias a un crédito hipotecario y a la ayuda de un grupo de ahorros. Para ilustrar la trayectoria hasta llegar al momento de compra de este inmueble, a continuación, se exponen los diversos traslados de la familia y la joven en Barcelona. En este caso, el testimonio se ha convertido en una narración elaborada por los autores a partir de las palabras de la informante:

El padre de la joven llegó a España en el año 2001, cuando su hermano pequeño tenía cuatro años. El objetivo era ganar dinero para tener una vida mejor. Su padre entró a España con visado de turista, pero luego se quedó en el país de forma irregular. En ese momento trabajaba en Granollers. Finalmente, gracias al proceso extraordinario de normalización de extranjeros realizado en España en el año $2005^{58}$, consiguió el permiso de residencia. Cuatro años después, con los ahorros fruto de su trabajo, la familia pudo reunificarse viniendo a España, la madre, el hermano menor y ella misma.

Cuando se reunificaron vivían en Granollers, donde ya residía anteriormente su padre por cercanía al lugar de trabajo. Toda la familia se alojaba en una vivienda compartida ofrecida por el dueño de la empresa donde trabajaba el padre: una habitación gratis, para el matrimonio, y otra habitación alquilada para los dos hijos. De este modo el alojamiento era más barato de lo habitual ya que sólo pagaban por el alquiler de una habitación 200 euros al mes.

Cuando el padre dejó el trabajo cambiaron de residencia. Entonces, toda la unidad familiar se trasladó a la zona de Hospital Clínic de Barcelona donde el padre y la madre encontraron trabajo. En esta zona también se alojaron con las mismas condiciones que en Granollers, viviendo en un domicilio propiedad del dueño de la empresa con el cual trabajaban juntos: les ofrecía una habitación gratuita y otra alquilada por 300 euros mensuales. En ambas viviendas, en Granollers y en Barcelona, compartían la residencia con otros trabajadores.

En el año 2011, dejaron el trabajo en Hospital Clínic. Después de acumular un cierto capital, decidieron abrir su propio negocio y pidieron el dinero que les faltaba a su grupo de ahorros para poder adquirir un bar que estaba en traspaso en el barrio de Sants de Barcelona. Con el préstamo que obtuvieron pudieron hacer frente al traspaso del bar, que era lo suficientemente rentable para devolver el préstamo sin problemas.

Después de trasladarse desde Granollers hasta Barcelona-Hospital Clínic, la familia se ha cambiado de domicilio cinco veces más, pero siempre dentro de la misma zona, Sants, cerca del bar que regentan. Todos los traslados se han debido al cambio de trabajo, para estar cerca del lugar de la actividad laboral. Conforme la familia cambiaba de una vivienda a otra, las condiciones del domicilio mejoraban: al

58 De febrero a mayo del 2005 el gobierno español permitió a migrantes obtener permiso de residencia si demostraban que habían residido en España desde antes de agosto del 2004 con un contrato de trabajo mínimo de seis meses. 
principio, se alojaban en pisos compartidos con trabajadores y, luego, consiguieron alquilar una vivienda unifamiliar.

En el año 2017, la familia decidió comprar un piso en la zona de Les Corts. Aunque ya disponían de un cierto capital y contaban también con la ayuda proporcionada por el grupo de ahorros, solicitaron información a un banco español sobre las hipotecas para comprar vivienda. En su caso, el piso de alquiler donde vivían, que contaba con tres habitaciones, costaba 700 euros al mes y la hipoteca del nuevo eran 850 euros mensuales, teniendo cuatro habitaciones. Finalmente, decidieron pagar 150 euros más al mes para comprar la vivienda en vez de pagar alquiler. Además, el piso nuevo también está cerca del bar, factor importante que tuvieron en cuenta en el momento de elegir la vivienda.

Esta vivienda les costó 300.000 euros aproximadamente. Como pago inicial, dieron el 30\% del total del precio, y para cubrir el 70\% restante tienen un préstamo concedido por un banco. La vivienda está a nombre de los padres y del hermano pequeño, no de la joven. El motivo principal que los padres piensan volver a China al jubilarse y así, cuando retornen, la vivienda continuará con un titular presente, su hermano, que pueda gestionarla y, por ejemplo, alquilarla, ya que él no tiene una intención clara de volver a China.

Esta familia tenía su propia casa en un pueblo cerca de la ciudad Fuzhou, la capital de la provincia de Fujian. Al trasladarse a España su casa quedó deshabitada. En los primeros meses del año 2016, la familia decidió comprar un piso en la ciudad de Fuzhou, cambiando su residencia desde su antigua vivienda del pueblo a un nuevo domicilio en la capital de la provincia. Los motivos principales para realizar esta adquisición fueron: 1) El deseo de los padres de volver a China para pasar su vejez; 2) Para que el hermano pequeño de la informante disponga de una vivienda en China en caso de compromiso matrimonial ${ }^{59}$; 3 ) Evitar dificultades para comprar vivienda debido a la posible implantación futura de cláusulas de restricción de compra de vivienda por parte del gobierno chino ${ }^{60}$.

La adquisición del piso nuevo en China se llevó a cabo cuando la familia ya estaba en España, invirtiendo el dinero ganado en España para la compra de vivienda en China. La informante y su familia sabían que el precio de la vivienda en China está en constante aumento y que el gobierno iba a aplicar nuevas normas para controlar la compraventa de viviendas, por lo que si retrasaban la decisión de compra

59 Los padres chinos consideran que sus hijos varones necesitan una propiedad inmueble para ofrecer a su futura esposa en el momento del matrimonio. En el caso de las hijas no es necesario que tenga ninguna propiedad, ya que al casarse la aportará su futuro marido. Por eso, el piso de Fuzhou está a nombre de los padres y del hijo varón, no de la joven migrante. De acuerdo a la informante esta práctica es la costumbre y no se siente molesta por no tener el título de propiedad de esa vivienda.

60 Durante la entrevista, la familia mostró su convencimiento de la imposibilidad de comprar vivienda fácilmente en el futuro debido a medidas como las que se implantaron posteriormente. Algunas de las medidas fueron, por ejemplo, "La Notificación Relativa al Constante y Sano Desarrollo del Mercado Inmobiliario" que limitó la compra de inmuebles prohibiendo a los bancos conceder préstamos mayores del $40 \%$ del precio del inmueble y la obligación del pago inicial del $60 \%$ del precio total al comprar una segunda vivienda. 
se encontrarían ante la situación de no poder hacerlo a causa del nuevo contexto.

Para la adquisición de la vivienda, la familia volvió a China para visitar el piso y la ciudad. El pago inicial fue de 700.000 yuanes, el 30\% del precio total de la vivienda. Para comprar este inmueble, la familia solicitó un crédito hipotecario al Banco de China, ya que tienen el hukou rural registrado en su pueblo, municipio que forma parte de esa ciudad de Fuzhou, dándole derecho a adquirir vivienda en la misma.

Debido al pago mensual del crédito hipotecario, la familia, de vuelta en España, mantiene un vínculo a largo plazo con China. Cada mes, el banco paga la mensualidad del crédito hipotecario abonado por su cuenta bancaria china. Debido a la dificultad para hacer transferencias desde la cuenta bancaria española a la china y para evitar gastos de comisiones por transferencia, por la tasa de cambio de divisas, ${ }^{61} \mathrm{y}$ para ganar tiempo, la informante buscaba a alguien dispuesto a cambiar yuanes por euros en efectivo. ${ }^{62}$ Hasta el momento de la entrevista solo tenían un contacto chino a quien recurrir: una estudiante china necesitaba un saldo de 5.000 euros en su cuenta bancaria para renovar su NIE. ${ }^{63}$ Esa cantidad de dinero no es suficiente para cubrir sus necesidades, ya que la hipoteca de yuanes es a largo plazo y, por eso, continúan la búsqueda de más contactos chinos para cambiar divisas.

Finalmente, la compra de la vivienda en Fuzhou en ese momento fue satisfactoria, ya que poco después se aprobó una nueva medida de control de compraventa de viviendas en la ciudad capital: la obligación de realizar el pago inicial del $70 \%$ del precio total de la vivienda para poder adquirirla. La vivienda fue comprada gracias a la recomendación de una pariente que era la promotora de ventas de las viviendas de la zona residencial donde compraron.

Los anteriores testimonios muestran de una forma directa la estrecha relación entre movilidad, residencia y trabajo en el contexto de la migración china en España, además de los vínculos residenciales transnacionales que se continúan manteniendo con China. Los testimonios dan cuenta de los cambios de situación residencial con el paso del tiempo, a menudo vinculados al establecimiento y la ampliación de

61 Normalmente, la tasa de cambio de divisas comporta un coste variable que puede aumentar por el doble cambio de moneda. Los bancos chinos siempre cambian de euros a dólares y, luego, de dólares a yuanes, tanto en la entrada como en la salida de capital de las cuentas bancarias chinas. 62 Algunos empresarios chinos tienen ingresos que no pueden justificar, motivo por el que no los pueden ingresar en el banco. Normalmente, guardan su capital en efectivo en casa, lo cual les preocupa por la seguridad. Así, los nuevos residentes chinos -los inversores por la Ley de Emprendedores- en España, que tienen cuentas bancarias en China, acuerdan con algún empresario chino en España el hacerle una transferencia a su cuenta, también en China, de una cierta cantidad de dinero en moneda china. De esta forma, la segunda parte le dará la misma cantidad de dinero en euros, según la tasa de cambio, en efectivo. Los nuevos residentes realizan dicha transferencia mediante internet o aplicación móvil de su banco chino, por lo tanto, no es necesario que vayan a China para tramitar esta operación. En el momento de haber realizado la transferencia, el residente certifica el trámite al empresario y éste prepara el dinero en efectivo para dárselo.

63 Para la renovación del NIE el gobierno español solicita el documento acreditativo de disposición de medios económicos necesarios para el período de permiso de residencia del NIE y para el retorno al país de procedencia. Para ello, normalmente los estudiantes chinos aportan un certificado de saldo de su cuenta española. 
empresas y con la necesidad de nueva mano de obra, o del ciclo de vida familiar: de soltero a casado; de pareja sin hijos a tener hijos; de familia nuclear separada entre China y España a la reunificación familiar en España; la oferta de alojamiento en la vivienda propia a otros familiares, e incluso a empleados, etc.

\section{Conclusión}

La trayectoria residencial de los migrantes chinos es semejante a las de otros orígenes, en el sentido de que todos pasan por las mismas fases residenciales: vivienda de emergencia, vivienda de transición y vivienda estable. Los motivos de traslado de vivienda de los chinos residentes en España, dependen, principalmente, de su vida laboral y de su disponibilidad y poder económico. De forma más concreta, la elección de vivienda obedece a los siguientes criterios: 1) proximidad al lugar de trabajo: al llegar à España, recurren a una vivienda cerca del trabajo para evitar el coste del traslado y así aumentar el ahorro; 2) mejora de condiciones de vivienda: en el momento de transición, se tiene en cuenta otros factores como la calidad de la vivienda, sin dejar de lado la proximidad al trabajo; 3 ) acumulación de capital para inversión en vivienda: cuando se ha logrado una considerable acumulación de capital, el objetivo del cambio residencial es su inversión en una vivienda estable y que cumpla con sus expectativas, e incluso la inversión en otras viviendas con la finalidad de aumentar sus ingresos.

Debido a la acumulación de capital y la mejora de su situación socioeconómica, los migrantes mejoran progresivamente las condiciones de su alojamiento durante su trayectoria migratoria. De modo que pasan de vivir en pisos compartidos a pisos unifamiliares; de dejar, en algunos casos, el alquiler y pasar a la compra de vivienda, tanto en China como en España; y pasar de vivir en un pueblo o municipio pequeño a residir en una gran ciudad, en China y en España. Las condiciones de las viviendas también mejoran con el paso del tiempo, al igual que la zona donde se ubican, las instalaciones y equipamientos que poseen, las conexiones de transporte con la ciudad, etc.

Los migrantes chinos están distribuidos por toda la geografía española, aunque han desarrollado pequeñas concentraciones residenciales a lo largo del tiempo. Su dispersión está directamente relacionada con la apertura de negocios que suelen ser pequeñas empresas familiares en localizaciones donde la competencia entre ellos mismos sea menor, de ahí su aparición y establecimiento repentino en lugares donde antes no estaban, y su llegada a los mismos con capital suficiente para abrir los negocios y comprar vivienda. Otra peculiaridad es el recurso a préstamos de familiares y amigos para reunir el capital para comprar vivienda, sin excluir la posibilidad de solicitar créditos hipotecarios a las instituciones financieras. Finalmente, no hay que olvidar los vínculos residenciales transnacionales que incluyen el mantenimiento de vivienda en China, la construcción de casas nuevas y rehabilitación de las antiguas y la inversión en la compra de viviendas nuevas para fines residenciales o especulativos. En cuanto a los vínculos residenciales transnacionales también so- 
bresale la inversión de nuevo capital chino directamente procedente del país con el objetivo de conseguir el permiso de residencia en España tal y como permite la ley 14/2013. Los chinos ricos que llegan a España constituyen un nuevo segmento de la población a tener en cuenta en su evolución futura.

\section{Bibliografía}

ANDERSON, Kay J., The Idea of Chinatown: The Power of Place and Institutional Practice in the Making of a Racial Category. Annals of the Association of American Geographers, 77, 1991, pp. 580-598.

BAYONA, J. y LÓPEZ-GAY, A., Concentración, segregación y movilidad residencial de los extranjeros en Barcelona. Documents d'Anàlisi Geogràfica, 57 (3), 2011 , pp. 381-412.

BELTRÁN ANTOLÍN, Joaquín, Expansión geográfica y diversidad económica. Pautas y estrategias del asentamiento chino en España. Ponencia presentada al II Congreso sobre la Inmigración en España. Madrid: Instituto Universitario de Estudios sobre Migraciones de la Universidad Pontificia Comillas e Instituto Universitario Ortega y Gasset, 2000.

BELTRÁN ANTOLÍN, Joaquín, Remesas y redes familiares desde China a España, en Ángeles ESCRIVA y Natalia RIBAS, coords. Migración y desarrollo. Estudios sobre remesas y otras prácticas transnacionales en España. Córdoba: CSIC, Instituto de Estudios Sociales de Andalucía, 2004, pp. 285-312.

BELTRÁN ANTOLÍN, Joaquín, The Seeds of Chinatown. Chinese Entrepreneurship in Spain, en Ernest SPAAN, Felicitas HILLMANN y Ton VAN NAERSEN, eds., Asian Migrants on the European Labour Markets. Londres: Routledge, 2005, pp. 285-308.

BELTRÁN ANTOLÍN, Joaquín, La presencia china en España: Globalización y transnacionalismo, en Fundació Seminario de Investigación para la Paz, ed., La emergencia de China e India en el siglo XXI. Zaragoza: Gobierno de Aragón. Departamento de Educación, Cultura y Deporte, 2009a pp. 249-271.

BELTRÁN ANTOLÍN, Joaquín, La inmigración china en Cataluña", en Joan JULIÀMUNÉ, ed., Visions de la Xina: cultura multimil.lenària. Lleida: Institut d'Estudis Ilerdencs de la Diputació de Lleida, 2009b, pp.125-150.

BELTRÁN ANTOLÍN, Joaquín y SÁIZ LÓPEZ, Amelia, Población y actividades económicas de las comunidades asiáticas en España", Documento CIDOB-Asia, $\mathrm{n}^{\mathrm{o}}$ 10, 2006.

BELTRÁN ANTOLÍN, Joaquín y SÁIZ LÓPEZ, Amelia, Empresariado asiático en España. Barcelona: Fundación CIDOB, 2009.

BELTRÁN ANTOLÍN, Joaquín y SÁIZ LÓPEZ, Amelia, Del restaurante chino al bar autóctono. Evolución del empresariado de origen chino en España y su compleja relación con la etnicidad, en Magdalena BARROS NOCK y Hugo VALENZUELA GARCÍA, eds., Retos y estrategias del empresariado étnico. Estudios 
de caso de empresarios latinos en los Estados Unidos y empresarios inmigrantes en España. Centro de Investigaciones y Estudios Superiores en Antropología Social (CIESAS): México, D.F., 2013, pp. 85-108.

BELTRÁN ANTOLÍN, Joaquín y SÁIZ LÓPEZ, Amelia, A contracorriente. Trabajadores y empresarios chinos en España ante la crisis económica (20072013). Migraciones, $\mathrm{n}^{0} 37,2015$, pp. 125-147.

BERNARDOS, Gonzalo; MARTÍNEZ-RIGOL, Sergi; FRAGO, Lluís.; CARRERAS, Carles, Las apropiaciones de la ciudad a la hora de la globalización: Las estrategias del capital ruso y chino en el mercado inmobiliario de Barcelona. Scripta Nova:

Revista Electrónica de Geografía y Ciencias Sociales, 18 (493) 52, 2014, pp. 1-17.

BILDIMEIER, S. S. L., Spaces of Alterity and Temporal Permanence: The Case of San Francisco and New York's Chinatowns, en O. KALMEIER, ed., Selling EthniCity: Urban Cultural Politics in the Americas. Surrey: Ashgate, 201 1, pp. 275-285.

BRAY, David, Social Space and Governance in Urban China. The Danwei System from Origins to Reform. Stanford: Stanford University Press, 2005.

CARRIL-CACCIA, Federico; MILGRAM-BALEIX, Juliette, Inversiones directas chinas en España. Cuadernos Económicos de ICE, 94, 2017, pp. 115-135

CHENG Tiejun; SELDEN Mark, The Origins and Social Consequences of China's Hukou System. The China Quarterly, 139, 1994, pp. 644-668

CHRISTIANSEN, Flemming, ed., Chinatown, Europe. Identity of the European Chinese towards the beginning of the 21st century. Londres: Routledge Curzon, 2003.

CLARK, William A. V.; HUANG Youqin, The Life Course and Residential Mobility in British Housing Markets. Environment and Planning A, 35, 2003, pp. 323-339. DOI:10.1068/a3542.

COULTER Rory; VAN HAM, Maarten, Following People through Time: An Analysis of Individual Residential Mobility Biographies. Housing Studies 28 (7), 2013, pp. 1037-1055.

COULTER Rory; VAN HAM, Maarten; FINDLAY, Allan M., Re-thinking Residential Mobility: Linking Lives through Time and Space. Progress in Human Geography 40 (3), 2016, pp. 352-374.

DUVA, Jesús, Descubiertos tres talleres clandestinos de confección donde trabajaban 29 chinos. El País, 16 de marzo de 1991.

https://elpais.com/diario/1991/03/16/madrid/669126254_850215.html

EFE, Clausuran un taller clandestino de confección en el que explotaban a chinos. El Periódico de Aragón, 16 de marzo de 2007.

http://www.elperiodicodearagon.com/noticias/sociedad/clausuran-tallerclandestino-confeccion-explotaban-chinos 307162.html

FONG, T., The First Suburban Chinatown: The Remaking of Monterey Park, California. Philadelphia: Temple University Press, 1994.

FULLAONDO, Arkaitz, Inserción y lógica residencial de la inmigración extranjera en la ciudad. El caso de Barcelona. Tesis Doctoral Inedita. Barcelona: UniversidadPolitécnica de Cataluña, 2008

GARCIA ALMIRALL, Pilar; FRIZZERA, Agustín, La trayectoria residencial de la inmigración en Madrid y Barcelona. Un esquema teórico a partir del análisis 
cualitativo. Revista ACE, III (8), 2008, pp. 39-52.

GARCÍA COLL, Arlinda; LÓPEZ VILLANUEVA, Cristina; PUJADAS RÚBIES, Isabel (2016) "Movilidad residencial en tiempos de crisis. El caso de la Región Metropolitana de Barcelona". Scripta Nova. Revista Electrónica de Geografía y Ciencias Sociales. [En línea], 20 (549-4). http://www.ub.es/geocrit/sn/ sn-549-4.pdf

GIL-ALONSO, Fernando; PUJADAS RÚBIES, Isabel, Migraciones intrametropolitanas de los extranjeros: diferencias y semejanzas en las metrópolis de Barcelona y Madrid. Cuadernos de Geografía, 93, 2013, pp. 27-52.

GIL-ALONSO, Fernando; BAYONA-I-CARRASCO, Jordi; PUJADAS RÚBIES, Isabel, Las migraciones internas de los extranjeros en España: Dinámicas espaciales recientes bajo el impacto de la crisis. Boletín de la Asociación de Geógrafos Españoles, 69, 2015, pp. 233-261.

HIDALGO, C., Una empresaria esclavizaba a inmigrantes en talleres textiles ilegales de Brunete. $A B C, 11$ de diciembre de 2013.

http://www.abc.es/madrid/20131211/abci-empresaria-esclavizaba-inmigrantestalleres-201312111225.html

KÜNNEMANN, Vanessa; MAYER, Ruth, eds., Chinatowns in a Transnational World: Myths and Realities of an Urban Phenomenon. Nueva York: Routledge, 2011.

LI, W. Anatomy of a New Ethnic Settlement. The Chinese Ethnoburb in Los Angeles. Urban Studies, 35 (3), 1998, pp. 479-501.

LIU-FARRER, Gracia, Migration as Class-based Consumption: The Emigration of the Rich in Contemporary China. The China Quarterly, 226, 2016, pp. 449-518.

MALLEE, Hein, Rural-Urban Migration Control in the People's Republic of China: Effects of the Recent Reform, China Information, 1 1, 1988, pp. 12-22.

MARTÍNEZ-RIGOL, Sergi; FRAGO, Lluís; MORCUENDE, Alejandro; CARRERAS, Carles; BERNARDOS, Gonzalo, Barcelona's New Chinatown: Chinese Strategies in the Housing Market in Barcelona and Globalization. Urban Science 1, (1), 5, 2017, pp. 1-15.

MCDONOGH, Gary W., Chinatowns: Heterotopic Space, Urban Conflict, and Global Meanings. Quaderns-e, 18 (2), 2013, pp. 96-111.

MIRET, Naik y Pau SERRA DEL POZO, El papel de la inmigración extranjera en el cambio social y urbano del Besòs i el Maresme, un barrio periférico de Barcelona. Interrogaciones a partir de un estudio exploratorio. Estudios Geográficos, 74 (274), 2013, pp. 193-229

PALOMARES-LINARES, Isabel; FERIA TORIBIO, José María; SUSINO ARBUCIAS, Joaquín, Medida y evolución de la movilidad residencial en las áreas metropolitanas españolas. Papers. Revista de Sociologia, 102 (4), 2017, pp.545574

PEREDA, Carlos; ACTIS, Walter; PRADA, Miguel Ángel, Inmigración y vivienda en España, Madrid: Ministerio de Trabajo y Asuntos Sociales, Subdirección 
General de Información Administrativa y Publicaciones, 2005.

PEREIRA, Sandra Marques; BRINGÉ, Arnaud; FERREIRA, Ana Cristina, Residential Trajectories in Lisbon Metropolitan Area: An Exploratory Approach. Cidades, Comunidades e Territórios, 28, 2014, pp. 1-17.

PUMARES, P., GARCÍA, A.; ASENSIO, A., La movilidad laboral y geográfica de la población extranjera en España. Madrid, OPI, Ministerio de Trabajo y Asuntos Sociales, Documentos, nº 10, 2006.

RECAÑO, J., La movilidad geográfica de la población extranjera en España: un fenómeno emergente. Cuadernos de Geografía, n 72, 2002, 135-156.

RECAÑO, J., La consolidación de las migraciones internas de inmigrantes como factor estructural de la movilidad geográfica en España. Panorama Social, 24, 2016, pp. 49-71.

RECAÑO, J y DOMINGO, A., Evolución de la distribución territorial y la movilidad geográfica de la población extranjera en España, en AJA, E. y ARANGO, J. (eds.) Veinte años de inmigración en España: perspectiva jurídica y sociológica (19852004), Barcelona: CIDOB, 2006, pp. 223-256.

RECAÑO, J. y DE MIGUEL, V., The Internal Migration of foreign-born Population in Southern Europe: Demographic Patterns and Individual Determinants, en FINNEY, N. y CATNEY, G. (Ed.) Minority Internal Migration in Europe, Ashgate, International Population Studies, 2012, pp. 239-262

SABATER, A.; BAYONA, J.; DOMINGO, A., Internal Migration and Residential Patterns across Spain after Unprecedented International Migration. En N. FINNEY y G. CATNEY, eds., Minority Internal Migration in Europe. Ashgate, Farnham, 2012, pp 293-311

SÁIZ LÓPEZ, Amelia, Gender, Development and Asian Migration in Spain: The Chinese Case, en Laura OSO y Natalia RIBAS-MATEOS (eds.) The International Handbook on Gender, Migration and Transnationalismo: Global and Development Perspective, Cheltenham y Northampton, Edward Elgar, 2013, pp. 165-184.

SANJUAN, Thierry, ed., Les Chinatowns : trajectoires urbaines de l'identité chinoise à l'heure de la mondialisation. París: Grafigéo, UMR PRODIG, 2017.

SERRA DEL POZO, Pau, Los procesos geográficos de concentración en las centralidades étnicas". Revista Internacional de Organizaciones, 2, 2009, pp. 89108.

SERRA DEL POZO, Pau, Dispersión y suburbanización. Nuevos paisajes étnicos. Revista Internacional de Organizaciones, 6, 201 1, pp. 65-79.

TÉBAR, Jesús. Mapa del Chinatown de Madrid. Madrid: Bubok Publishing, 2011.

THUNO, Mette, ed., Beyond Chinatown: New Chinese Migration and the Global Expansion of China. NIAS - Nordic Institute of Asian Studies, Copenhagen, 2007.

WONG, Bernard, P.; TAN Chee-Beng, eds., The Chinatown around the World. Gilded Ghetto, Ethnopolis, and Cultural Diaspora. Leiden: Brill, 2013.

WONG, Cindy Hing-Yuk; MCDONOGH Gary W., Negotiating Global Chinatowns: 
Difference, Diversity and Connection. Cambio. Rivista sulle Transformazioni Sociali, 3 (6), 2013, pp. 41-54. DOI: 10.1400/218587

YAMASHITA, K., Formation and development of Chinatown in Japan. Chinatowns as tourist spots in Yokohama, Kobe and Nagasaki. Geographical Review of Japan, 76, 2003, pp. 910-923.

(c) Copyright: Wanchu Zhong, Joaquín Beltrán Antolín, 2020

(c) Copyright: Scripta Nova, 2020.

Ficha bibliográfica:

ZHONG, Wanchu; BELTRÁN ANTOLÍN, Joaquín. Vivienda y movilidad. Comportamiento residencial de la migración china en España. Scripta Nova. Revista Electrónica de Geografía y Ciencias Sociales. Barcelona: Universidad de Barcelona, l de enero de 2020, vol. XXV, $\mathrm{n}^{\circ}$ 629. [ISSN: 1138-9788] 